\title{
AGNIESZKA RUMIANOWSKA
}

Państwowa Wyższa Szkoła Zawodowa

w Płocku

\section{O ISTOCIE JĘZYKA W PROCESIE EDUKACJI ZE SZCZEGÓLNYM UWZGLĘDNIENIEM PROCESU KSZTAŁCENIA JEZZYKOWEGO}

\begin{abstract}
Rumianowska Agnieszka, O istocie języka w procesie edukacji ze szczególnym uwzględnieniem procesu ksztatcenia jezzykowego [Abaut the Essence of Langauge in the Process of Education with Special Attention to Language Education]. Studia Edukacyjne nr 41, 2016, Poznań 2016, pp. 261-271. Adam Mickiewicz University Press. ISSN 1233-6688. DOI: 10.14746/se.2016.41.16

The article names the problem of a language, its essence and the way the reality is described by it. The author undertakes an attempt to integrate pragmatic, effictive and correct aspects of language education with the problem of relavancy and the meaning of language aktivities. She pays special attention to deep intimate hermeneutic relationship beetween human being and his language and the moral and etical issues of language education and language activity. In the second part of the article the autor indicates the necessity of integrating pragmatic purposes connected with language knowlege and communicative skills with the purposes of general education, which creates the possibility of cognitive and emotional development of pupils.
\end{abstract}

Key words: language, human being, experience, narration, education, langauge education

Niemal w każdym słowie naszego języka - jak pisał niegdyś W. Doroszewski ${ }^{1}$ - tkwi pierwiastek swoistego piękna, a on odsłania się nam za każdym razem wówczas, kiedy zaczynamy postrzegać język bezinteresownie, gdy słowa pozbawione swojej powszedniości rzeczywiście zaczynają wyrażać nasze autentyczne przeżycia i odczucia. Dopóki jednak słowa używane są wyłącznie do określenia bliżej nieokreślonych i niedoświadczonych rzeczy o abstrakcyjnej wartości, rzeczy te tracą swoją konkretność, a człowiek

\footnotetext{
${ }^{1}$ W. Doroszewski, Rozmowy o jezzyku, Warszawa 1948, s. 57.
} 
przestaje przeżywać to, o czym mówi. To, co wówczas pozostaje, to abstrakcyjne słowa, pojęcia ogólne. Człowiek zaczyna ich używać głównie po to, aby wypełnić lukę, pustkę zarówno wewnątrz niego samego, jak i podczas komunikowania się z innymi². Innymi słowy, wypowiada komunikaty, zdania, nie dzieląc się rzeczywistością, o której właśnie mówi. Nierzadko wypowiada je z pewną nutą zakłopotania i niepewności, i w taki sposób, aby można było jak najłatwiej i najszybciej ukryć pustkę rozmów, nie odczuwając przy tym żadnych emocji i uczuć. W ten sposób słowa przestają się liczyć, a język staje się wyalienowany, z tendencją do abstrahowania od konkretnych doświadczeń i przeżyć. W najbardziej skrajnych przypadkach człowiek pytany o własne samopoczucie, mimo że czuje się nieszczęśliwy, osamotniony i niepewny, odpowiada niezgodnie z prawdą i własnymi odczuciami, jakie właśnie przeżywa. Często dzieje się tak między innymi dlatego, iż zakłada on z góry, że pytająca go o jego samopoczucie osoba, tak naprawdę nie jest szczerze zainteresowana faktycznym stanem, $w$ jakim się on znajduje.

Źródeł takiego stanu wyobcowania człowieka, instrumentalnego i powierzchownego podejścia do języka, należy doszukiwać się zarówno w uwarunkowaniach społecznych i kulturowych, w których przyszło żyć współczesnemu człowiekowi, jak również w obrazie współczesnej edukacji, $\mathrm{w}$ tym w wymiarze kształcenia językowego, którego projektowanie zwykło się rozpoczynać od odpowiedzi na pytania o kwestie praktyczne, pragmatyczne i użyteczne, w miejsce stawiania pytań fundamentalnych o istotę języka, o relację między człowiekiem a językiem, a także o etyczny, naznaczony językowo stosunek człowieka do drugiego człowieka.

\section{Język jako integralna część psychicznej i duchowej sfery człowieka}

Język to nie tylko zdania i reguły nimi rządzące, to nie tylko kompetencja językowa i komunikacyjna, lecz również "swoiście ludzka praktyka, praktyka konstytuująca człowieka", istotna część psychiki człowieka, część własnego Ja w wymiarze ludzkim i duchowym. Jak ujął to W. Humboldt³, język to "wiecznie powtarzająca się praca ducha" nad wyartykułowaniem tego, nad czym pracuje umysł. Innymi słowy, to proces, działająca siła,

\footnotetext{
2 E. Fromm, Patologia normalności. Przyczynek do nauki o człowieku, Kraków 2013, s. 57.

${ }^{3}$ W. Humboldt, Rozmaitość języków a rozwój umysłowy ludzkości, Lublin 2001, s. 77.
} 
„energeia”, a nie tylko produkt, „ergon”. To twór i wytwór zarazem. Mowa stanowi przy tym wewnętrzną potrzebę człowieka, leżącą $\mathrm{w}$ jego naturze, która nie odnosi się tylko do podtrzymywania komunikacji, lecz przede wszystkim do rozwijania jego sił umysłowych, intelektualnych oraz do zyskiwania określonego poglądu na świat, a także kształtowania obrazu samego siebie.

W tak rozumianej koncepcji języka nie może być zatem mowy o przeprowadzaniu jego analiz w oderwaniu od użytkownika, jak również wyodrębniania poszczególnych funkcji języka. Język może bowiem występować $\mathrm{w}$ różnych funkcjach, ale $\mathrm{w}$ żadnej z nich nie daje się zamknąćd. Istota języka polega między innymi na tym, że repertuar jego funkcji pozostaje niezamknięty. Tak jak istoty człowieka nie da się sprowadzić do jednej funkcji, tak i języka nie da się opisać w kategoriach prostego zjawiska. Nie jest on bowiem zwykłym narzędziem czy też instrumentem, którym posługuje się człowiek. Język to przede wszystkim integralna część emocjonalnej, kognitywnej, duchowej i cielesnej sfery człowieka. U podstaw takiego założenia leży kompleksowa, złożona koncepcja języka, a także założona koncepcja człowieka jako bytu niepowtarzalnego, niemierzalnego, unikatowego i wyjątkowego.

Jedną z osób, które w dwudziestym wieku szczególnie wyraźnie eksponowały ontologiczny związek człowieka z językiem był H.G. Gadamer. $\mathrm{Z}$ punktu widzenia uprawianej przez niego hermeneutyki filozoficznej, prawdziwy byt języka wyraża się w tym co mówione, co absorbuje, co niesie znaczenie, co jest nastawione na sens, a nie tylko na skuteczność działania 5 . Najbardziej istotne $\mathrm{w}$ języku jest to, co $\mathrm{w}$ nim powiedziane, co tworzy wspólny świat z innymi ludźmi. Aby można było mówić o języku w rozumieniu hermeneutycznym, wiedza i umiejętności językowe muszą być połączone $\mathrm{z}$ doświadczeniem egzystencjalnym jednostki, rozumianej jako byt trójskładnikowy psychiczno-cielesno-duchowy, jako jedność która rozumie, a jednocześnie oczekuje potwierdzenia siebie dzięki rozumieniu przez innych ${ }^{6}$. Człowiek postrzegany jest tu jako byt złożony, bogaty, którego nie da się w całości ująć w sposób poznawczy. Jego życie jest obarczone zawsze pewną nieokreślonością i nieoznaczonością. W każdym człowieku istnieje odrębny świat wewnętrznych doświadczeń, przeżyć i możliwości.

${ }^{4}$ G. Godlewski, Stowo o antropologii stowa, [w:] Antropologia stowa. Zagadnienia i wybór tekstów, red. G. Godlewski, Warszawa 2013, s. 9.

${ }^{5}$ H.G. Gadamer, Język i rozumienie, Warszawa 2013, s. 38.

${ }^{6}$ M. Sawicki, Hermeneutyka pedagogiczna, Warszawa 1996, s. 37. 
Źródłowej istoty języka należy się doszukiwać przede wszystkim tam, gdzie ma miejsce artykulacja procesów psychicznych i duchowych człowieka, wynikających z jego głębi, z naturalnej potrzeby wyrażenia własnych, autentycznych odczuć, przeżyć, własnego poglądu na świat. Istota języka znika natomiast, kiedy człowiek powtarza cudze zdania. To, co wówczas powstaje, to pseudomowa. Jak powiada M. Heidegger ${ }^{7}$, mówienie i powiadanie nie są tym samym. Ktoś może mówić i mówić bez końca, a i tak nic to nie będzie powiadać, to jest - nie będzie pozwalać na ujawnienie się, na widzenie, na słuchanie. Prawdziwy byt języka jest „czymś najbardziej niepozornym ze wszystkiego pozornego, czymś najprostszym ze wszystkiego prostego, najbliższym ze wszystkiego bliskiego". Mowa jest wydarzeniem. To wydarzenie nie ma nic wspólnego z jakąś normą, regulacją, instrukcją, porządkiem, czy też z gotowym wzorcem. Mowa jest żywa i prawdziwa tylko wówczas, kiedy człowiek wyraża to, co w nim rzeczywiste, gdy jest sobą, kiedy nie udaje. Nie jest to jednak zadanie łatwe, wręcz przeciwnie najtrudniej poznać samego siebie, odnaleźć prawdę o samym sobie, prawdę słów, prawdę najprostszych gestów, prawdę o ludzkiej twarzy człowieka ${ }^{8}$. Nie jest łatwo odejść od złudzenia, udawania, okrągłych, dobrze zaplanowanych i poskładanych zdań, poubieranych masek, dwuznaczności, pozorów i zaprogramowanych gestów.

\section{Istota języka w kontekście edukacji}

Skoro zatem język jest tak ściśle, intymnie zintegrowany z człowiekiem, stąd w procesie edukacji nie może być mowy o bezrefleksyjnym powielaniu, schematycznym powtarzaniu, o rozwijaniu kompetencji komunikacyjnej wyłącznie poprzez wyuczenie się reguł składających się na poprawność językową, czy też sprawne użycie technik i strategii komunikacyjnych. Ważne staje się czynienie $\mathrm{z}$ języka narzędzia ekspresji i to zarówno w obszarze myśli, uczuć, jak i własnych doświadczeń, włączając $\mathrm{w}$ to całą osobowość, potrzeby i dążenia człowieka. Aby było to jednak możliwe, muszą zostać najpierw stworzone korzystne warunki do uaktywniania całej istoty człowieka. Chodzi tu o uruchomienie jego doświadczeń, wyobraźni, kreatywności, możliwości intelektualnych, a także o otwarcie się na drugiego człowieka i rozwijanie zdolności do empatii oraz tolerancji. W praktyce oznacza to nic innego, jak odejście od zbytniej koncentracji jedynie na aspek-

\footnotetext{
${ }^{7}$ M. Heidegger, $W$ drodze do jezzyka, Warszawa 2007, s. 228, 235.

8 J. Tischner, Jak żyć, Wrocław 2012, s. 105.
} 
tach jednoznacznych, użytkowych, a przez to powierzchownych, nie stwarzających szans na zaistnienie naturalnej potrzeby wyrażania tego, co dzieje się w sferze psychicznej i duchowej człowieka. Warto dodać, że nawet jeśli treści prezentowane są w procesie edukacji w sposób ciekawy i motywujący, to i tak ma to jedną zasadniczą wadę, że uczący się często nie mają sobie nawzajem $\mathrm{w}$ rzeczywistości nic do powiedzenia. Ten sam problem pojawia się przy konieczności podania „prawidłowych”, „właściwych" odpowiedzi albo oczekiwanych od nauczyciela, albo wymuszonych schematyczną, wzorcową formą ćwiczeń. Choć wypowiedzi takie mogą być pod względem merytorycznym, gramatycznym, semantycznym dobrze sformułowane i bezbłędne, to jednak nie ma to nic wspólnego z wyżej przedstawionym ujęciem języka.

Wśród osób, które jako pierwsze dostrzegły w procesie edukacji potrzebę porzucenia materialistycznego i czysto obiektywnego postrzegania procesu uczenia się i używania języka był J.H. Pestalozzi. Za punkt wyjścia kształcenia człowieka uważał on naturę ludzką, z całym bagażem jej zdolności, sił, potrzeb i możliwości. Mając to na uwadze, krytykował czysto instrumentalne podejście do języka, poleganie jedynie na logice rozumu, przy jednoczesnym zaniedbywaniu wewnętrznych przeżyć dziecka. Jak twierdził,

wszelka nauka, której definicje zjawiają się w duszy dzieci jak deus ex machina, albo raczej muszą być jak przez suflera $\mathrm{w}$ teatrze trąbione $\mathrm{w}$ ich uszy, wszelka nauka idąca takim tropem musi stać się nędzną komedią kształcenia9.

Przestrzegał ponadto przed nieodpowiedzialnym użyciem języka, grą słów, stwierdzając, iż tak długo jak człowiek nosi w sobie chęć uszlachetnienia się przez język, tak długo język staje się dla niego wielką świętością, ale kiedy nie jest jego godzien, gdy zaczyna go używać bez wewnętrznego pragnienia swego doskonalenia, staje się on pierwszym środkiem prowadzącym do zguby.

Na gruncie współczesnej edukacji ciekawe poglądy na temat sensu i istoty podejmowanej aktywności językowej w ramach procesu edukacyjnego głosiła w dwudziestym wieku znana niemiecka dydaktyk języka E. Essen. Twierdziła, że

jeśli mamy do czynienia z językiem, to mamy do czynienia z człowiekiem. Jeśli pracujemy nad językiem człowieka, to dotykamy w ten sposób jądra jego istoty i działania ${ }^{10}$.

${ }_{9}^{9}$ J.H. Pestalozzi, Pisma pedagogiczne, Wrocław 1972, s. 351. 
Stąd też, celem m.in. kształcenia językowego nie może być w żaden sposób tylko to co powierzchowne, techniczne, pragmatyczne, lecz próba uaktywnienia całego człowieka, zachęcenie go do analizowania rzeczywistości, obserwowania samego siebie, twórczej refleksji, do uwolnienia w nim siły ekspresji, jak i naturalnej potrzeby komunikowania. Dopiero uruchomienie szerokiego spektrum intelektualnego i afektywnego potencjału jednostki rodzi autentyczną potrzebę poszukiwania językowych środków, które by dawały wyraz jej spostrzeżeniom, przemyśleniom i doświadczeniom. Zdaniem E. Essen, prawdziwe działanie językowe wyrasta z wewnątrz, z woli przeniesienia tego, co człowiek odczuwa, myśli i przeżywa na język. Nie wynika to więc wyłącznie z opanowania wiedzy, abstrakcyjnych pojęć, czy bezrefleksyjnego wyćwiczenia umiejętności językowych i komunikacyjnych. Takie techniczne i instrumentalne podejście do języka może nawet oznaczać niebezpieczeństwo dla istoty człowieka, ponieważ skłania go do powierzchownej zręczności i gry słowami, bez odpowiedzialności. Człowiek nie mówi wówczas tego co myśli, czuje, widzi, słyszy, lecz wypowiada się według jakiś gotowych wzorców. Język - przypomina niemiecka badaczka11 to instrument humanizmu, dany do dyspozycji każdemu w trochę inny sposób i włączony w różne horyzonty życia, ale pozostawiony każdemu $\mathrm{w}$ ramach odpowiedzialności $\mathrm{w}$ celu odnalezienia i określenia samego siebie, porozumiewania się z innymi, jak i obcowania ze światem oraz rzeczywistością.

\section{Problem \\ etycznego (i językowego) stosunku człowieka do człowieka}

Opisywanie siebie za pomocą języka, artykułowanie własnych przeżyć, doświadczeń i myśli staje się porażką wówczas, kiedy człowiek dostrzega, że druga strona go nie "słyszy" i nie rozumie. Jeszcze większe cierpienie zaczyna doskwierać człowiekowi wtedy, kiedy nie pozwala się jemu na prawdziwość, gdy jego wypowiedź jest oceniana, zniekształcana, czy jeszcze gorzej - ośmieszana. Jest to kolejna ważna kwestia pojawiająca się w kontekście edukacji, w tym w zakresie kształcenia językowego. To kwestia etycznego stosunku człowieka do człowieka. Zapytywanie i odpowiadanie, artykułowanie swoich potrzeb, dążeń i przemyśleń na niewiele się zda, jeśli

${ }^{10}$ E. Essen, Bildung durch Sprachbewusstsein und sprachliches Gestalten, Frankfurt am Main 2002, s. 25.

11 Tamże, s. 259. 
pominięty zostanie problem uszanowania prawa drugiego człowieka do tego samego. Ważne jest zatem uświadomienie sobie, że każdy człowiek jest indywiduum wolnym, rozumnym, decydującym o sobie, biorącym odpowiedzialność za własne cele. Ważne jest zrozumienie, że „Inny” jest w końcu takim samym człowiekiem jak Ja. Ważne jest doświadczenie, że "każdy $\mathrm{z}$ nas jest człowiekiem, a dopiero potem istnieje element odmienności, istnieje w sposób szczególny"12. Wreszcie ważne jest zaakceptowanie faktu, że człowiek nie jest ani narzędziem, ani środkiem do używania drugiego człowieka i nie jest też środkiem potrzebnym do zaspokojenia potrzeb innych. Bez otwarcia się na drugiego człowieka, bez dostrzegania w nim czegoś dobrego, bez nauczenia się „słyszenia”, a nie tylko „słuchania”, nie może być mowy o wzajemnym zrozumieniu, poznawaniu i odkrywaniu się nawzajem. Doświadczenie uczucia bycia niewysłuchanym i nierozumianym jest zawsze przeżyciem trudnym, pokazującym jeszcze bardziej doniosłość sztuki słuchania zarówno w relacji nauczyciel - uczeń, jak i w każdej innej relacji Ja Ty. Z punktu widzenia rzeczywistości edukacyjnej, budowanie etycznych, opartych na słowie, relacji międzyludzkich nie jest zadaniem łatwym, wręcz przeciwnie - wymaga ono porzucenia materialistycznego pojmowania natury ludzkiej, odejścia od powierzchownego, instrumentalnego ujęcia języka, a w zamian powrotu do „rzeczy samych”, nauczenia się postrzegania drugiego jako autonomicznego bytu i wykazywania się dużą dozą wrażliwości i otwartości na drugiego człowieka. Jak głosił niegdyś E. Levinas ${ }^{13}$, zawsze można doświadczyć obecności drugiego człowieka, ale jednocześnie można też nie dostrzegać jego samego, jego "twarzy”, jego wezwania. I choć „Inny” to osoba, która do mnie przemawia, za którą jestem odpowiedzialny(a), to niestety zdarza się, że przechodzę obok niej obojętnie.

\section{Moc słowa w budowaniu doświadczenia życiowego człowieka}

Trudno sobie wyobrazić dobrze zaprojektowany i dobrze przemyślany proces kształcenia bez budowania świadomości, w jaki sposób język, użyte słowa i skonstruowane historie o samym sobie wyznaczają doświadczenie człowieka. Za pomocą języka człowiek wyraża samego siebie, swoje przeżycia, artykułuje przemyślenia, ale $\mathrm{z}$ drugiej strony użyte słowa, zbudowane narracje o własnym życiu określają bardziej lub mniej pozytywnie sposób

12 S. Kierkegaard, Czyny miłości, Kęty 2015, s. 149.

${ }^{13}$ E. Levinas, Całość i nieskończoność. Esej o zewnętrzności, Warszawa 2014. 
myślenia o sobie. Moc słowa jest tu nie do przecenienia. „Wszystko jest takie jakie jest na podstawie mniemania" - pisał już w drugim wieku naszej ery M. Aureliusz ${ }^{14}$, obrazując to dodatkowo w następujący sposób: „nie odczuwam przykrości, chyba że wydam sąd o pewnym zdarzeniu, że jest nieszczęściem. A mam moc nie wydawać sądu". To człowiek wybiera zatem perspektywę, wydobywa z pamięci takie a nie inne słowa, określenia, obrazy, sceny, sytuacje z własnego życia, łączy je w jedną całość, nadając im głębszy sens i motyw działania ${ }^{15}$. Jednocześnie w nieunikniony sposób eliminuje niektóre fakty, pomija, zniekształca albo zmienia. Wszystko to sprowadza się do całkowicie autonomicznej pracy umysłu, procesu konstruowania, wybierania, łączenia, porządkowania i aktywowania wyobraźni potrzebnej do wypełniania luk, pustych miejsc w łańcuchu życiowych zdarzeń. Jak ujął to J.P. Sartre ${ }^{16}$, "kiedy tylko żyjemy nie zdarza się nic", jednak "kiedy opowiada się życie, wszystko ulega zmianie”. Już sam fakt opowiadania może mieć znaczenie zmieniające, m.in. dzięki wydobywaniu z pamięci słów określających własne doświadczenie życiowe, poprzez ustosunkowywanie się do pewnych wydarzeń i poglądów, poprzez tworzenie opowieści o samym sobie, o innych, opowieści o osobistej zmianie, o zmianie postrzegania samego siebie i swojego sposobu myślenia. Takie komponowanie opowieści o życiu jest zawsze procesem wysoce elastycznym, podlegającym zmianom, a w sprzyjających warunkach również pozytywnym przemianom. Miejscem szczególnie odpowiednim do dokonywania takich właśnie pozytywnych przemian jest niewątpliwie przestrzeń edukacyjna. To właśnie edukacja jest tym, co daje szansę na przejęcie przez człowieka autorstwa, na tworzenie pełniejszych, ciekawszych, bardziej pozytywnych i budujących obrazów samego siebie, na kwestionowanie sztywnych i ubogich wzorców interpretacyjnych, czy wreszcie na określanie za pomocą opowiadanych historii swojego stosunku do życia, własnych doświadczeń i poglądów.

\section{Wymiar praktyczny kształcenia językowego}

Zachęcanie młodego człowieka do wyrażania swojego doświadczenia w refleksyjny, niewymuszony sposób zakłada przyjęcie określonej perspekty-

${ }^{14}$ M. Aureliusz, Rozmyślania, Kęty 2015, s. 58-60.

15 J. Bruner, Życie jako narracja, Kwartalnik Pedagogiczny, 1990, 4, s. 5; T.R. Sarbin, The Narrative as a Root Metaphor for Psychology, [w:] Narrative Psychology. The Storied Nature of Human Conduct, red. T.R. Sarbin, London 1986.

${ }_{16}$ J.P. Sartre, Mdłości, Warszawa 1974, s. 74-76. 
wy postrzegania uczącej się jednostki. Uczeń to podmiot, człowiek z własnymi potrzebami komunikacyjnymi, możliwościami twórczymi, doświadczeniem emocjonalnym, społecznym i egzystencjalnym. Innymi słowy, to indywiduum myślące, $\mathrm{z}$ zasady kreatywne, przeżywające i poszukujące znaczenia, sensu oraz rozumienia otaczającej go rzeczywistości i siebie w niej. Uwzględnianie zainteresowań, doświadczeń, emocji, subiektywnych przeżyć i wiedzy uczącego się podmiotu, przyznanie mu prawa do własnego myślenia, interpretowania rzeczywistości, zachęcanie go do samodzielności i kreatywnego myślenia to tylko niektóre z zadań nauczyciela $\mathrm{w}$ ramach szeroko pojętego kształcenia językowego, którego nota bene nie da się przypisać tylko i wyłącznie do takiego, a nie innego przedmiotu, kursu czy też takich a nie innych zajęć $\mathrm{w}$ ramach określonego programu kształcenia. Ponieważ język - jak podkreślano już wyżej - to integralny element życia, kształcenia, myślenia, przeżywania człowieka i konstruowania rzeczywistości, stąd praca nad nim staje się wyzwaniem dla całego procesu edukacyjnego.

Nadanie procesowi kształcenia językowego głębszego sensu oznacza w praktyce m.in. 1) zachęcanie do pisania i mówienia na własny temat, do dzielenia się z innymi własnym doświadczeniem, odczuciami, takim a nie innym sposobem widzenia rzeczywistości; 2) zachęcanie do pisania twórczego, poszukiwania $\mathrm{w}$ ten sposób własnej niepowtarzalności i wartości; 3) tworzenie opowieści alternatywnych, które pomagają wydostać się z utartych, schematycznych sposobów myślenia; 4) budowanie bardziej pozytywnych, wartościowych obrazów samego siebie, np. z wykorzystaniem różnego rodzaju gier, zabaw, pomysłów metodycznych; 5) wyszukiwanie takich słów, które stają się doświadczeniem młodego człowieka, kluczem do zmiany odczuwania i myślenia o samym sobie; 6) uczenie się zastępowania wypowiedzi oskarżycielskich, gniewnych, obwiniających komunikatami konstruktywnymi, ujawniającymi własne odczucia i potrzeby; 7) uczenie się komunikowania w bardziej odsłaniający, refleksyjny sposób w zamian za podejmowanie prób zmieniania drugiej osoby; 8) wykorzystanie szerokiego wachlarza zróżnicowanych zadań, typologii ćwiczeniowej, mających na celu m.in. rozwijanie umiejętności aktywnego, empatycznego słuchania, rozwijania swojego słownictwa, poznawanie barier na drodze komunikacji czy też tworzenia konstruktywnych wypowiedzi zwrotnych; 9) położenie wreszcie większego nacisku na generowanie znaczeń wobec koncentracji na funkcjonalnych, użytecznych aspektach języka. 


\section{Zakończenie}

„Posłuchaj tego, co mówisz i zastanów się, czy rzeczywiście mówisz to, co chcesz powiedzieć" - ta prosta, wyrażona w niezwykle bezpośredni sposób, rada V. Satir ${ }^{17}$ w pełni oddaje sens poruszanych powyżej rozważań na temat istoty języka w życiu człowieka, a szczególnie w życiu człowieka młodego, podlegającego wpływom edukacyjnym. Refleksyjne posługiwanie się językiem, ostrożne użycie słów z należytą dbałością oraz świadomością ich wpływu na nasze "Ja", wpływu na stosunki emocjonalne między ludźmi, a wreszcie wpływu na sposób myślenia o swoim dotychczasowym doświadczeniu to tylko niektóre $\mathrm{z}$ zadań, jakie powinny być realizowane $\mathrm{w}$ procesie edukacyjnym, $\mathrm{w}$ tym $\mathrm{w}$ procesie kształcenia językowego. Błędem jest usiłowanie rozumienia i projektowania procesu kształcenia jedynie $\mathrm{w}$ kategoriach instrumentalnych, analitycznych, z pominięciem tego, co się dzieje w duszy człowieka, z pominięciem głęboko intymnej, hermeneutycznej relacji człowieka i języka oraz kwestii etycznego stosunku człowieka do człowieka. Być może warto byłoby zrobić taki „rachunek sumienia dla edukacji" i zapytać - jak uczynił to w jednym ze swoich wierszy J. Twardowski ${ }^{18}$ - dlaczego właściwie tak daleko odeszliśmy

od wzruszenia nie na niby, od sensu, od podziwu nad światem, od tego co nagie a nie rozebrane, od tego co wielkie nie tylko z daleka ale i z bliska, od tajemnicy nie wykładanej na talerz.

Innymi słowy, dlaczego $\mathrm{w}$ projektowaniu procesu edukacyjnego tak daleko odeszliśmy od istoty, od fundamentu, od źródłowego sensu języka.

\section{BIBLIOGRAFIA}

Aureliusz M., Rozmyślania, Wydawnictwo Marek Derewiecki, Kęty 2015.

Bloch E., Ślady, Wydawnictwo Uniwersytetu Jagiellońskiego, Kraków 2012.

Buber M., Problem człowieka, przekł. R. Reszke, Wydawnictwo Spacja, Warszawa 1993.

Buber M., Między osobq a osoba, [w:] Mosty zamiast murów, red. J. Stewart, przekł. J. Suchecki, Wydawnictwo Naukowe PWN, Warszawa 2014.

Bruner J., Życie jako narracja, Kwartalnik Pedagogiczny, 1990, 4.

Doroszewski W., Rozmowy o jezzyku, Radiowy Instytut Wydawniczy, Warszawa 1948.

17 V. Satir, Zwracanie uwagi na stowa, [w:] Mosty zamiast murów, przekł. J. Suchecki, red. J. Stewart, Warszawa 2014, s. 107.

18 J. Twardowski, Rachunek dla dorostego, [w:] Elementarz Księdza Twardowskiego, Kraków 2002. 
Essen E., Bildung durch Sprachbewusstsein und sprachliches Gestalten, Peter Lang Verlag, Frankfurt am Main 2002.

Fromm E., Patologia normalności. Przyczynek do nauki o człowieku, Wydawnictwo Vis-a-Vis Etiuda, Kraków 2013.

Gadamer H.G., Niezdolność do rozmowy, Wydawnictwo Znak, 1980, 3.

Gadamer H.G., Jezzyk i rozumienie, Wydawnictwo Aletheia, Warszawa 2013.

Godlewski G., Stowo o antropologii stowa, [w:] Antropologia stowa. Zagadnienia i wybór tekstów, red. G. Godlewski, Wydawnictwo Uniwersytetu Warszawskiego, Warszawa 2013.

Grucza F., O wieloznaczności wyrazu język, heterogeniczności wiązanych z nim desygnatów $i$ istocie rzeczywistych języków ludzkich, Przegląd Glottodydaktyczny, 1994, 13.

Heidegger M., W drodze do jezzyka, Wydawnictwo Aletheia, Warszawa 2007.

Humboldt W., Rozmaitość języków a rozwój umystowy ludzkości, Wydawnictwo Katolickiego Uniwersytetu Lubelskiego, Lublin 2001.

Kierkegaard S., Czyny miłości, Wydawnictwo Marek Derewiecki, Kęty 2015.

Levinas E., Całość i nieskończoność. Esej o zewnętrzności, Wydawnictwo Naukowe PWN, Warszawa 2014.

Mcadams D.P., The role of narrative in personality psychology today, Narrative Inquiry, 2006, $16,1$.

Pestalozzi J.H., Pisma pedagogiczne, Ossolineum, Wrocław 1972.

Roger C.R., Doświadczenia w komunikowaniu się, [w:] Mosty zamiast murów, red. J. Stewart, przekł. J. Suchecki, Wydawnictwo Naukowe PWN, Warszawa 2014.

Rumianowska A., About the importance of developing and improving communication skills on higher level education, General Professional Education, 2015, 2.

Sarbin T.R., The Narrative as a Root Metaphor for Psychology, [w:] Narrative Psychology. The Storied Nature of Human Conduct, red. T.R. Sarbin, London 1986.

Sartre J.P., Mdtości, Państwowy Instytut Wydawniczy, Warszawa 1974.

Satir V., Zwracanie uwagi na stowa, [w:] Mosty zamiast murów, przekł. J. Suchecki, red. J. Stewart, Wydawnictwo Naukowe PWN, Warszawa 2014.

Sawicki M., Hermeneutyka pedagogiczna, Wydawnictwo Semper, Warszawa 1996.

Tischner J., Jak żyć, Wydawnictwo Tum, Wrocław 2012.

Twardowski J., Elementarz Księdza Twardowskiego, Wydawnictwo Literackie, Kraków 2002. 
